tikel (de vorige twee alineas) aangestelde reviseuren, wordt in overleg mot de bankcommissie vastgesteld. Buiten deze belooning mogen de reviseuren geen voordecl, onder welken vorm ook, ontvangen.

Om tot den eed van reviseur te worden toegelaten, moet men door de hankcommissic worden crkend.

Deze makkt een erkemingsreglement op, dat den Minister van Openbar Onderwijs en den Minister van Finaneiën ter goedkeuring wordt roorgelegd.

Dit reglement bepaalt tevens de gevallen warin de erkenning kan worden ingetrokken.

De reviseuren legren den deskundigeneed af ten overstaan van den voorzitter van de bankeommissic of van het door hem gedelegeerd lid.

EIk reviseur geeft onmiddellijk, hetzij den bankier, hetzij elken bestuurder of behcerder van de bank, kennis van de onregelmatigheden en inbl'euken die hij mocht hebben vastgesteld. (Volgens onze meening, is bị deze wet een volledige controle voorgeschreven, en moeten alle geconstatcerde verschillen en afwijkingen, ook die welke buiten deze wet vallen door den reviseur onmiddellijk ter kennis van den opdrachtgever gebracht worden).

Elk reviseur die kemis heeft van een beslissing van de bank waarvan de uitvocring een strafbaar feit zou uitmaken, stelt zijn veto tegen deze uitvoering en legt de zaak onmiddellijk bij de bankcommissic voor. Het veto heeft een opschortende kracht van acht lagen. (Het zal echter regel zijn, dat de reviseur ccrst kennis van de overtredingen lirijgt, langen tijd nadat deze plaats gehad hebben, vooral als de contrôle slechts eenmaal per jaar geschiedt, en hoe hij in deze gevallen handelen moet, vermeldt de wet nict.)

De bepalingen van vorenstaand lid rijn evenwel niet van toepassing op overtredingen van fiscalen aard.

De reviseuren mogen, in de alan hun toezicht onderworpen lanken, geen ander ambt warnemen.

De reviseuren mogen geen door den staat, de provinciën of de gemeenten bezoldigd ambt bekleeden, noch een mandaat verrullen van bestuurder, directeur, beheerder, commissaris of procuratishouder van handelsvemootschappen of maatschappijen onder handelsvorm, behoudens door de bankcommissie te verleenen vergumning; deze vergumning kan steeds worden ingetrokken.

De reviseuren mogen hun functï̈n van reviscur bịj verschillende banken uitoefenen.

Een bank mag geen lecning toestaan, onder wolken vorm ook, aan de reviseuren dic hun funetiën bij haar uitoefenen. Hetzelfde rerbod geldt ook voor elke deelneming in cen waarborgsyndicat roor den groeden afloop ran een openbare uitgifte van effecten waarmede de bank belast is.

Onverminderd de verplichtingen welke hun bij de wet of reglementen zijn opgelegd en buiten het geval waarin zij in rechten grotuigenis moeten afleggen, mogen de reviseuren geenerlei foiten bekend maken warvan zij in verband met hun functiën kcunis hebben genomen.

Wat hetreft de strafhepalingen, betrekking helbende op de reviseurem is vooryien in deel IS van deze wet, deze luiden als volert :

Met een van de in artikel 179 der sanengevoegde wetten op de handelsvemootschappen vorziene straffen worden gestraft.

De revisenren die hetoij voordeel hetzij cen andero belooning aammenen dan die vastgesteld overeenkomstig de artikelen, (volgen de hierboven aangehaalde artikelen, betrekking hebbende op de belooning) of die nadat de erkenning hun werd ontnomen, de functies van revisen uitocfenen of die artikel 24 (andere functiën) overtreden;

Zij die de verificatiën verhinderen, waaraan zij rich moeten onderwerpen of weigeren inlichtingen te verstrekken welke zij krachtens dit besluit gehouden zijn te verstrekken, of die wetens en willens onjuiste of onvolledige inlichtingen geven.

Iedere inbreuk on de artikelen 25 of 40 (gcheimhouding) wordt gestraft met de bij artikel 458 van het Strafwethoek voorziene straffen.

Al deze strafbepalingen voorzien in geldstraffen en gevanganis en kumnen ook gelijktijdig toegepast worden.

In de overgangsbepalingen is nog vermeld, dat de eerste reviseuren voorloopig door den behcerrraad benoemd mogen worden, onder voorbchoud van definitieve benoeming door de cerstvolgende gewone algemeene vergadering van aandeclhouders

Aan het einde van ons rorig artikel spraken wij onze vermoedens uit, dat men te bevoegder plaatse niet wist, waar men de geschilte personen voor de nieuwe functiön van reviseureu zoeken moest. Inmiddals hebben wij kumnen constateeren, da.t deze vermoedens juist waren. Vier maanden na het verschijnen van de wet, en kort voordat deze in werking treedt, weet men nog niet wie men beëcligen kan of moet. Zullen het cxpertscomptable, waur men geen al te groot vertrouwen in heeft, juristen, waarvan er maar zeer weinigen administratief bekwaam genoeg zijn, of bankmenschen, welke men nict onpartijdig genoeg acht, zijn? Ook wordt er over een combinatie van de bekwamste onder deze groepen gedacht. Mromenteel weet echter nog niemand, welke eischen men stellen zal, en wij weten positicf, dat het nog wel veertien dagen zal duren, voordat de daartos aungewezen instanties het eens zullen zijn over de vaststelling van deze eischen.

E. GOUDSMIT

\section{UIT DE FINANCIEELE HUISHOUDING DER OVERHEID}

\section{Red.: J. H. TEXTOR}

(Bijdragen en mededeelingen zende men aan den Secretaris der Redactie)

\section{Nogmaals: Taxatie bij grondbedrijven}

'T'egen een cnkele opmerking. wolke wij ten aanzien van het bovenstainde onderwerp makten in de artikclen, die in de nummers van Yei en .Juni 1935 van dit tijdschrift zijn opgenomen, werd doon den heer B. B. L. bezwaar gemalakt in zijn in November on December 1.1. versehenen artikelenrecks in het tijdschriỉt .Financiec] Overheidsbeheer"', onder den titel ,.Pe. riodieke taxatie van het gemeentelijk grondberit". Wellicht komt spocdig do gelegenheid on daarop in andop verband terug te kemen.

Meer van helang lijkt het ons om hier te laten volgen hetgeen hij schrijft over de door ons naur voren gebrachte moci. lijkheden, die zich thans met betrekking tot de taxatie voordoen. Wij schreven darromtrent destijds liet navolgende:

Iv den tegenuoorligen tijd zullen de taxaties in vele gerallen doen zien, dat de boekwalde veel te hoog is. Ook bij verkoop van terreinen \%al deze warheid blijken. Volgchs de verordeningen moct het nadeclig verschil uit reserves worden gedekt of, indien dit niet gaat, door de 
gemecnte worden bijgepast. Mar hoc moct worden gehandeld, indien het verschil tussehen het getaxeerde of verkoopsbedrag en de bockwaarde zeer groot blijkt te zijn en de gemeente foch al op zwalce lasten zit? Vele gemeenten kunnen mu reeds zonder dergelijke verliez?n hun be. grooting nauwlịks sluitend maken.

IIct yal dan ook niet vreemd schijnen, dat er gemeenten zijn, die trachten de beheelsverordening op het punt van de taxatie gewijzigd te krijgen en wel in dien zin, dat deze renige jaren zal worden uitgesteld. Jet is duidelijk, dat het tegemoetkomen aan dere wenschen het effect van de veiligheidshepalingen geheel teniet zou doen. 'Toch kan het noodzakclijk zijn om iets te doen. In dergelijke gevallen zou wellicht kumnen worden overwogen om den termịn, bimen welken de gemeente het nadeelig versehil moet dekken, van vijf tot bijv. tien jaar to verlengen. Daarmede zou gepaard mocten gaan een nieuwe taxatie binnon vijf jaar. Iocht daarbij blijken, dat de lage schatting van de vorige maal uitsluitend aan de almormale tijdsomstandigheden is te wijten en dan weer een hoogere waarde aan de gronden kan worden tocgokend, dan ware alleen nog dekking te verlangen van het nadeelig verschil, dat na de tweede taxatie nog tusschen de taxaticwarde en de boekwarde zal bestan.

Uit het bovenstaande moge blijken van hoeveel belang het rormen van cen groote reserve bij het grondbedrijf is. Er zijn dan ook gomeenten, vooral daar, waar de kans op het vormen van leserves uit winst lijj rerkoop niet workt verwacht, waar jarlijks nit de gemeentekas cen bedrig in het reserrefoncls van het bedrijf wordt gestort.

De Heer $L$. merkt nu het navolgende op:

..Fedeputeerde Staten dienen in stede van de tot nu toe geaischte 5-jaarlijksche taxatie, van elke gemeente, die ten behoeve van haar grondbedrijf jaarlijks de renter en aflossingen op de grondleeningen uit de buitengewone middclen bestrijat, te eischen, dat daartegenover de gemennte aan haar grondbedrijf moet dotecen de helft van het geleden renteverlies."

en verder:

„Ik heb er mij dikwijls over verwonderd, dat alle eolleges van Gedeputeerde Staten het huidige stelsel hebben geaccepteerd. Het valt torh nict te ontkennen, dat in ecn grondbedrijf een geweldige risico kan schuilen. Daarom zullen naar mijn meening Gedeputeelde Staten eerst dan de zalak volkomen dienen, wammer ze van de gemeenten eischen, dat zij een stevige reserve volmen in hun grondbedrijven. I aajom gevocl ik er veel voor on te vorderen. dat jaarlịks de helft van het renteverlies uit de gewone midaclen moet komen.

Eventuede reëele verliezen kumnen dan in alle geval vool cen groot deel worken bestreden uit de reserve. Ik hel mij voorgesteld de helft van het renteverlies, omdat ik het eenerzijds niet billijk acht, alle risico naar liet nageslacht te rersehuiven, anderzijds het niet juist neht alles op het tegenwoordige geslacht te laten drukken. Men zal het, naar ik meen te mogen verwachten, met mij ecns zijn, dat, indien dit systeen werd gevolgd, de taxatiecommissies zouden kunnen verdwijnen.

Ik herhaal: de directeur van het bedrijf, die met do toekomstplannen bekend is, kan, als hij dat wil, desnoods jaarlijks zich een globaal inzicht in den stand van zaken verschaffen. Blijkt er een reëel verlies, dan kan de ge- meente ol) de buitengewone middelen in ontvangst eerst de reserve vermelden.

ITil men niet de gewone middelen extra bezwaren om h.r. in 5 jaren het ongedekte verlies te doen verdwijnen, dan kan men gewoon het lceningsplan afwerken en konen jarrlijks de renten en aflossingen in plaats van op "Mnitengewoon" op ,gewoon". Het bedrag der reserve, lat de gomeente uit het grondhedrijf heeft geput, kan voor buitengewone uitgaven worden aangewend, desnoods voor nieuwe grondaankoopen, of kapitalsuitgaven van het bedrijf. Extra aflossen op de gesloten grondleeningen zal vrijwel stecds onmogelijk wezen. Blijkt de reserve nict noodig te zijn omdat cen complex voordeel heeft opgeleverd, welnu, daarvan profitecren dan in de toekomst alle inwoner's der gemeente."

Hut door den IJeer $L$, gcopperde denkbeeld lijkt ons zeer zeker de mocite ran het overwegen waard. Zijn standpunt stemt feitelijk overeen met lict onze, dat het voor de gemeenten, die cen grondbedrijf bezitten, zeer gewenscht is om tot reservevorming over te gaan. Inderdaad komt zijn idee, om den halven rentelast te laten dragen door den gewonen dienst, hierop neer. Alleen: het middel helpt nu niet meer voor de meeste gemecnten: het is slechts een roede raad (die ook nu duur is) voor de tockomst!

()verigens zourlen wij den Heer $L$. niet gaarne volgen bij ziju roolstel on dan de officieele taxatie maar achterwege te laten. Immers, zonder nog rekening te houden met de bijgeschreven lente, zou het wel eens kumnen blijken, dat de waarde der gronden (vooral thans) veel en recl lager is dan de oor. spronke] ịke aankoopswaarde. I Let komt ons voor, dat het niet te verdedigen is om het nadeelig versehil to verdeelen over den looptijd der deshetreffende leeningen. IIet nageslacht wordt op deze wijze te zwall bolast voor cen mislukte speculatic van het tegenwoordige. Ook een dergelijk nadeclig taxatieverschil hoewol het kleiner zal zijn dan onder de tegenwoordige omstandigheden. behoort o.i. in cen klein aantal jaren te worden gedekt.

\section{J. H. 'TEX'TOR}

UIT HET BUITENLAND
Red.: CH. HAGEMAN, Drs. A. TH. DE LANGE,
(Bijdragen en mededeelingen zende men aan den Secretaris
der Redactie)

\section{Recht op uitvoering van een ontvangen opdracht}

In The Aceountant van 7 Dee. 19:55 wordt van het volgende voorral melding gemiakt, dat hoewel niet passend roor de Hollandsche verhoudingen $\mathrm{mij}$ toch wel belangwckkend genoeg voorkomt on dit te releveeren. Len accountant was in Januari als auditor angesteld bij een private limited company voor het bockjaar cindigende op 30 September d.a.r. (op den 30en sept. werd op de algencene vergadering cen andere accountantsfirma benoend voor het volgende boekjaar. Op 1 October vervoegde de eersthedoelde accountant zich ten kantore der vemnootschap, teneinde de controle over het zoo juist verstreken bockjaar aan te vangen, doch hen werd inzage der boeken geweigerd. De accountant reclamerde hierop het honorarium over een jaar, doch de remootschap weigerde te betalen op grond, dat geen arbeid was verricht. Volgens de Redactie van The Accountant heeft de accomtant volgens de jurisprudentie weinig kans van slagen met cen proces. Al zal deze een actie tegen ongemotiveerd ontslag kunnen winnen dan nog zal hij 